\title{
FUNDAMENTUM - A PANELES LAKÓÉPÜLETEK FÖLDSZINTJE
}

\author{
BENKÖ MELINDA* - BALLA REGINA** \\ *PhD, tanszékvezető egyetemi docens. BME Urbanisztika Tanszék. \\ 1111 Budapest, Müegyetem rkp. 3. K 293. E-mail: benko@urb.bme.hu \\ **PhD-hallgató. BME Urbanisztika Tanszék. E-mail: regii.br@gmail.com
}

\begin{abstract}
A kutatás alapja az a feltételezés, hogy a paneles lakótelepek komplex megújítása városépítészeti léptéket követel, melyben az épületek földszintjei, a külső és belső térkapcsolatok újraértelmezése kiemelt fontosságú. A problémakör feltárása a hazai nagypaneles épületek földszintjeinek építészeti kialakítására épül. A cikk a rendelkezésre álló katalógusok alapján egyrészt a talajközeli térhatár (zárt, áttetsző vagy árkádos), másrészt a nyílások (bejárati ajtó, lakásablak, erkély, kapu, kirakat, közös tér ablaka, gépészeti nyílás, átjáró) tipológiáját állítja fel. Ezt a lakó és látogató számára fontos alsó szintet - a tömegterméket, a paneleket tartó, viszonylag sokféle, az adott helyhez is alkalmazkodó fundamentumot - nemcsak a panelházak építési korában, de az elmúlt évtizedek felújításai során is elhanyagolták. A müszaki vagy látványmegoldások alig érintik, így az épített környezetből a használatot terhelő problémák, mint például a rossz szubjektív biztonságérzet, a találkozások tereinek kerülése, az alulhasznosítottság stb. megmaradnak. Az írás a panelföldszintek építészeti megoldásainak összefoglalását adja, rávilágít az ezekből adódó használati problémákra, felhívja a figyelmet a témakör kiemelt kezelésének fontosságára.
\end{abstract}

Kulcsszavak: paneles lakótelep, panelház, földszinti zóna, térhatár és nyílástipológia, környezeti bünmegelőzés

Közép- és Kelet Európában, illetve a volt Szovjetunió területén 53 millió, az 1960-as, 1970-es, 1980-as években épült panellakás van, ami jelenleg és várhatóan 150-170 millió ember otthona. A volt kommunista országokban, változó arányban, de a lakosság 15-70\%-a panelban él, míg Nyugat-Európában ez az érték 10\% körüli. Magyarországon összesen 519679 lakásban közel 2 millió, a budapesti lakosság harmada, a székesfehérvári, miskolci fele panellakó (KSH 2011). A számok nagyságrendje egyértelmüvé teszi, hogy korunk és térségünk egyik legjelentősebb településtudományi kihívása a panel lakótelep összetett, a fizikai és társadalmi környezetet együtt kezelő értékelő elemzése. Ezt felismerve a Budapesti Müszaki és Gazdaságtudományi Egyetem Urbanisztika Tanszékén az elmúlt években egyre több kutatómunka és városépítészeti terv témája a panel lakótelep (http://www.urb.bme. hu/uhlab/prefabmh/).

Jelen írás a témát egy sajátos nézőpontból vizsgálja: a hazai paneles lakótelepek lakóházai földszintjeinek kialakítását tipizálja, majd a paneles épített adottságok értékelésén keresztül rávilágít a használat különböző, de természetesen egymással is 
összefüggő problémáira. A címben megjelenő fundamentum szó három elméleti és gyakorlati háttérre utal: a fizikai alapokra, az alsó szint építészeti kialakítására; a leginkább érzékelhető, belakható térrétegre, a fundamentálisra (Hajnóczi 1990); és a megújítás olyan alapkérdéseire, amik a rendszerváltást követő elmúlt 25 évben kimaradtak a hazai panelprogramok többségéből. A kutatás nemzetközi és hazai szakirodalomra, terepmunkákra és esettanulmányokra, illetve a szerzők által 2014-ben készített interjúkra (Bálint Imre, Callmeyer Ferenc, Roth János, Virág Csaba) támaszkodik. A hazai panelházak földszinti zónájának tipológiája korábbi saját munkákra épülnek (Balla 2014, Benkő 2006). A kutatásvezető 2013 és 2015 között szakértője volt tíz európai várost lakótelepeik megújítási törekvésein keresztül összefogó európai együttmüködés, az UrbAct Re-Block projektnek (http://urbact.eu/re-block), másrészt magyar képviselője a környezeti bünmegelözés multidiszciplináris témakörben, elsősorban lakótelepeket elemző európai uniós munkacsoportnak (http:// costtu1203.eu/).

Az előregyártás és az iparosítás a 19. század végétől az egyik legjelentősebb müszaki, mérnöki kutatási, tervezési terület. A II. világháború utáni urbanizáció, a tömeges lakásépítés idején, 1950 és 1970 között, több mint 400 különböző előregyártási módszert szabadalmaztattak (Bélaval 2011). A kommunista országokban, így hazánkban is a kínálat persze ennél sokkal szükösebb volt, a megvalósítás hatékonysági szempontjai felülírtak szinte minden mást. Hol volt a helye a korban a városépítészet olyan - a térhasználathoz kötődő - „részletkérdéseinek”, mint a lakóház földszinti zónájának kialakítása: a bejárat, a lépcsőház, a közös helyiségek, vagy az épületóriás és a külső terek viszonya, az átmeneti terek vagy a szabad térformálás (Karlóczainé 2012)?

A nagypaneles házgyári technológia lehetővé tette a gyors és viszonylag egyszerü, normatívákra alapozott tervezést és tömeges építést. Budapestet az 1965 és 1974 között épült négy házgyár (a Szentendrei úti, a ferencvárosi, a dunakeszi és a budafoki) látta el előregyártott, eleinte kizárólag szovjet (pl. az első paneles lakótelep, Kelenföld), majd dán (pl. Zugló központ) és hazai (pl. Káposztásmegyer) fejlesztésü elemekkel. A tervezést nemcsak az adott technológia, modul- és raszterrendszer korlátozta, hanem az éppen még raktáron lévő készlet felhasználási kötelezettsége is. A lakótelep-építés folyamatsémája szerint az ötéves tervek, a tizenöt éves lakásépítési koncepciók és az Általános Rendezési Tervek alapján kijelölték a helyszínt, megadták a lakásszámot és a kötelezően alkalmazandó technológiát. Majd általában országos rendezési terv- vagy ötletpályázat zajlott le (rendezési tervkoncepció beépítési javaslattal), ez alapján véglegesítették a beruházási programot, elkészült az 1/500-as léptékü beépítési terv (pl. Budapesten a BUVÁTI vagy a Lakóterv készítette). Párhuzamosan zajlott a meglévő lakó- és középületek adaptálása, esetleg újak tervezése (pl. Lakóterv, Típustervező Vállalat) és a szakági tervezés (utak, közmüvek, szabad terek stb.).

Az építész feladata az adott épülettípuson belül a közlekedőterület minimalizálása, minél több lakás elhelyezése, illetve a lakáson beüli lehető leghatékonyabb helykihasználás. Tény, hogy a nagypaneles építési mód esetén a földszint volt a leg- 
kevésbé tipizálható, hiszen a különböző terepadottságok (bejárat kialakítása) és a lakótelepen belüli eltérő lokalizáció (a terület határán vagy bent, útra merőlegesen vagy azzal párhuzamosan, közlekedési vagy zöldterület közelében stb.) viszonylagos sokféleséget kívánt.

1976-ban, az Építésügyi és Városfejlesztési Minisztérium Műszaki Tervezési Főosztálya kiadta a Panelos lakóépületek típusterv katalógusát (ÉVM 1976), melynek célja az 1965-töl alkalmazott nagypanelek korszerüsítése, az építéstechnológiát továbbra is használó lakásépítés változatosabbá tétele volt (pl. fesztávnövelés, sarokszekció megjelenítése stb). A dokumentációban a homlokzatok rajzai is megjelennek, 15 különböző földszintváltozatot ábrázol. A paneles lakóházak alapozását minden esetben monolit vasbeton fogadó szerkezet biztosította, a bemutatott megoldások felében ez a földszinti zóna zárt része, lehetetlen a térfal feltörése, a külső terekkel is kommunikáló helyiségek létrehozása. Feladata kizárólag tartószerkezeti. A dokumentáció nem ábrázol közös helyiségeket a földszinten, a szerkezet a lehetséges használatot és helyiségméretet erösen megköti. A típushomlokzati rajzokon földszinti nyílások jelennek meg, de ezek a valós helyszín, funkciók és a tervező elképzelései szerint kisebb-nagyobb mértékben módosíthatók voltak.

\section{TÉRHATÁR-TIPOLÓGIA}

A paneles lakóházak esetén a külső nyilvános és a belső félprivát vagy magán tereket a földszintet határoló falfelület vagy átmeneti tér választja el, minősége nemcsak a belső helyiségek kialakíthatóságát, hanem a külső tér fundamentális, használati zónáját is meghatározza. A paneles építési technológia következtében alakíthatósága korlátolt, ezért a panelek mai használatának, a környezetalakításnak meghatározó eleme.

\section{ZÁRT FÖLDSZINTI FAL (A1-A8. ÁBRA) ${ }^{1}$}

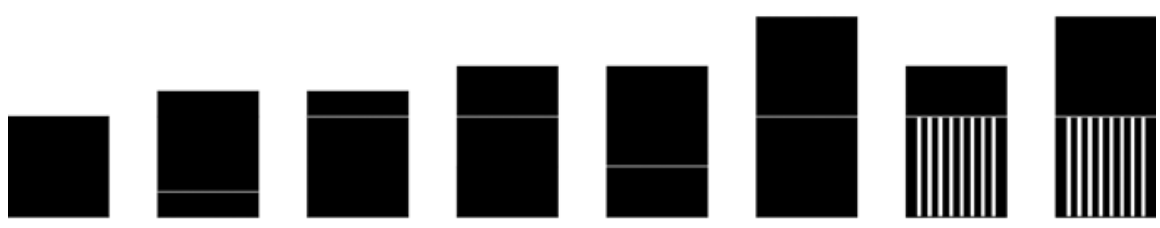

A közép- és kelet-európai paneles lakótelepeken - a modern nemzetközi urbanisztikai elveket szélsőségesen alkalmazva - a terület- és az épülethasználat egyaránt monofunkciós. A lakóházban csak lakások vannak. Így a használati szempontból a

${ }^{1} \mathrm{Az}$ ábrákat $(A-J)$ Balla Regina készítette. 
földszint a tervek figyelmen kívül hagyott része, elsősorban a nagyméretü épület müszaki alapja. A hazai gyakorlatban általában monolit vasbeton fogadószerkezetre épül rá 4, 5 vagy 9 nagypaneles lakószint. Ez a fogadószerkezet lehet félig a földbe süllyesztett, az első lakásszint a félemeletre kerül, és a tárolókkal, gépészeti helyiségekkel beépült pince természetes megvilágítása és szellőzése érdekében kis nyílásokkal tagolt monolit falazat jelenik meg a talajszint felett. Előfordul, hogy az egész földszint nyersbeton vagy panelelemekkel burkolt monolit, a lépcsőházi, nem akadálymentes, megemelt bejáratokon kívül teljesen zárt. A burkolat panelek a monolit szerkezetre állnak és általában már a földszinti, magasföldszinti lakásokat határolják $(A 2, A 5)$. Sok esetben a monolit fogadószint teljes panelmagasságban kiemelkedik a földfelszín fölé. Ilyenkor a földszinten gépészeti helyiségek és garázsok vannak (A1). A földszinti tömör falak egy panel egységnél magasabb kialakítása nem jellemzö, a néhány kivételnél a felső tömör egységben $(A 3, A 4, A 6)$ egyedi panelelem épült be. Külön említendők azok az általánostól eltérő szerkezetü panel földszintek, melyeknél a falsíkból kimozduló díszítő vasbeton sávok erösítik a fundamentum tömörségének, zártságának érzetét $(A 7, A 8)$.

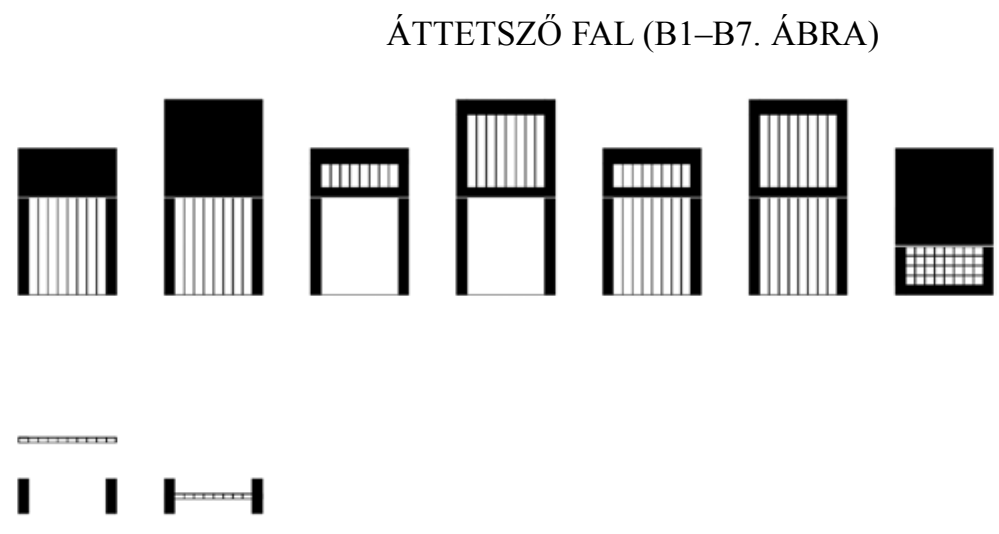

Áttetszőség esetén nincsen valós használati, térbeli kapcsolat a külső és belső tér között, de a két tértartomány hat egymásra, kölcsönösen érezhető a létük. Az áttetsző fal fizikailag elzár, a külső esetleg zavaró tényezöket (szagok, zajok) az épületen kívül tartja, a transzparenciának köszönhetően a külvilág fénye, látványa bejut a belsőbe. A nagypaneles technológia alkalmazása mellett, a földszinti tartószerkezetet pillérváz és a közlekedőmagok köré épített monolit mag adja, a külső falsíkra szintmagasságú (B2) vagy vízszintes osztással tagolt elöre gyártott kopolit üvegpanelek kerülnek $(B 5, B 6)$. Budapesten azonban erre kevés példát találni, gyakoribb, hogy ezek az üvegpanelek a gépészeti, első szintet határolják (B3, $B 4)$, a pinceszint kap üvegtégla bevilágító felületet (B7) vagy az üveg az árkádos megoldás kiegészítője, az elötér határa $(B 1)$. 
ÁRKÁD (C1-C9. ÁBRA)

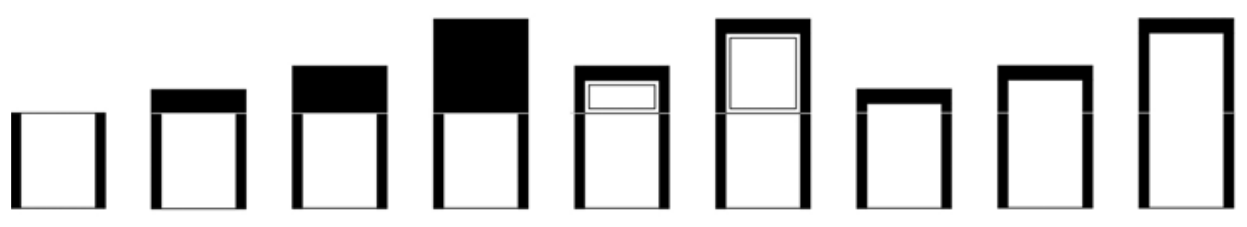

A monolit fogadószintes épületek zárt falfelületeivel szemben, a lábakra állított panelházak földszintjén, a külső és belső határán átmeneti tér létezik (Benkő 2006). Azonban a paneles lakókörnyezetben ez általában nem térbeli gazdagságot, többletet nyújt, hanem inkább feleslegként van jelen. Ennek oka nemcsak kialakításának építészeti minőségével magyarázható, hanem a használat problémáival is: az épületen kívüli külső terekkel nincs miért kommunikáljon, nincs körülötte valós városi közeg, illetve az épület belső terei sem tudják intenzíven müködtetni, a bejáraton kívül nincs más, az árkádra nyíló helyiség. A Le Corbusier által definiált modernista öt pont egyike a lábakra állított ház, alkalmazásának célja nemcsak a táj átvezetése az épület alatt, hanem a szabad alaprajzi és homlokzati formálás. Sok hazai panel áll lábakon, de a nagypaneles technológia miatt az épület nem valódi pillérvázas, nincs szabad alaprajz és homlokzat sem, ráadásul a nyomott földszinti belmagasság nem teszi lehetővé a ház „ellebegtetését” sem. Az eredeti modernista koncepcióból csak a lényeg hiányzik.

A paneles lakótelepeken sáv- és pontházaknál egyaránt építettek árkádot. Sok esetben a lakótelep gyalogos útvonalát ritmizálja az egymás után felfüzött házak alá befutó, ezáltal néha fedett út, ahonnan az épület bejárata is nyílik. Fő́tvonal menti sávháznál a hosszhomlokzatot kíséri részben vagy teljesen végig az árkád $(C 1, C 2)$, biztosítja a ház mentén a fedett végighaladást, elsősorban a tömegközlekedési megállótól a kapualjig való eljutást, esetleg egy-egy betelepült szolgáltató, kereskedelmi egység megközelítését $(C 7, C 8, C 9)$. Ảrkádos panelnél viszont csökkent a földszinti hasznos alapterület, ezért a gépészeti funkciók gyakran a földszint feletti, fél vagy egy szint magas technikai szintre kerültek $(C 3, C 4, C 5$, C6). A hazai paneles lakótelepeken a 60 -as évek Team 10 csoporthoz köthető városépítészeti, építészeti találmánya, az emelt utca, a deck nincs jelen. Az alapkoncepció szerint a gyalogosok a jármüvektöl teljesen elválasztva, a házak mentén és a házak között kialakított gyalogos utakon mozognak, így mindenki, a gyerekek is biztonságosan és könnyen bejárhatják a telepet, eljuthatnak egymáshoz és az iskolába. A deck alatti és feletti rész is egyfajta árkád, hol az épület részeként bent vagy mellette kint, az első szinten halad, hol önálló építményként kígyózik a házak között. A budapesti Újpalota, melynek tervezési mintája Toulouse-le-Mirail, az egyetlen olyan lakótelep, ahol egy rövid szakaszon felismerhető az emelt utca koncepció (Csízy 2012). 


\section{NYÍLÁSTIPOLÓGIA}

A földszinti zónát, külső és belső lehetséges kapcsolatát, a térhasználatot meghatározó másik épített elem a nyílás. A nagypaneles építésnél, a lehetőségekhez mérten, törekedtek a földszinti nyílások tipizálására is, de az a fajta homogenitás, ami általában a lakószinteket jellemzi, itt elmaradt. A tipizálásnál elöször a lakófunkcióhoz kötött nyílások, majd az azoktól függetlenek szerepelnek.

\section{BEJÁRATI AJTÓ (D1-D11. ÁBRA)}
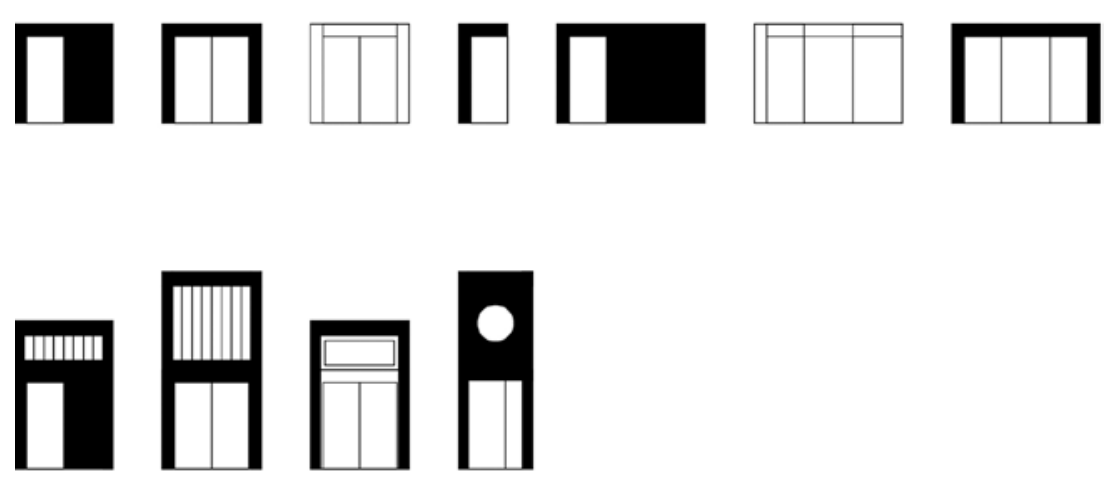

Az ajtó az egyik legváltozatosabb elem a panelépítészetben. A földszinti bejáratok általában egyben a lakosok által használt átjárók is, a panel sávházak két oldala közti használati különbséget kialakításuk érzékelteti. Van egy föbejárat és egy hátsó kijárat. Ezek szerepe a tájolástól, a közösségi közlekedés megállójának vagy a parkolóknak a helyétől, a kiszolgáló funkcióktól (pl. hulladéktároló) stb. függ. A főbejárat ajtaja minden esetben hangsúlyos, általában üvegfelületekkel körbevett, egy egész vagy akár egy annál nagyobb panelben elhelyezett nyílás. A mellékbejárat méretében és megjelenésében is elmarad a föbejáratitól, a legtöbb esetben csak minimálisan tér el egy átlagos lakásbejárati ajtó méretétől. Anyagukat tekintve a két típus nem különbözik, többnyire fémkeretben elhelyezett szintén fém, üveg vagy faborítással kivitelezett nyílászáró. Amennyiben a lakószint és a külső talajszint nem azonos magasságban van, a bejárati ajtókhoz vagy a belső térben tartozik a lépcsőháztól független vagy már annak részeként használt lépcső, vagy az épület előtt jelenik meg a lépcsőpihenő, esetleg előtető, előtérfal. 

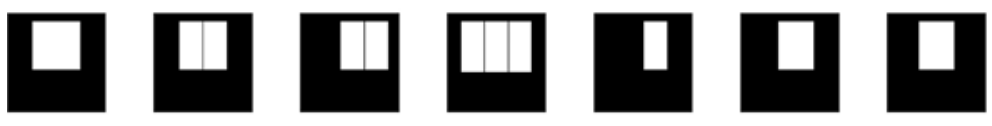

Kezdetben a szovjet típusú panellakóházakban (pl. Kelenföld sávházai) a földszinten vagy a félig földbe süllyesztett pinceszinten szerviz szintet alakítottak ki, mely a lakóközösséget szolgáló funkciókat és a gépészeti tereket rejtette, de később a lakásszám maximalizálása érdekében a földszintre is kerültek lakások. Ennek következményeként a földszinti homlokzaton is megjelennek az adott típusház lakásablakai, eltünik a „fundamentum”, a magánélet tere közvetlenül rányílik a közterületre.

\section{ERKÉLY (F1-F4. ÁBRA)}

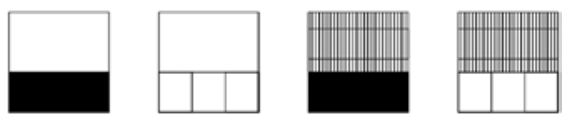

A földszinten létesített lakásokhoz erkélyek is tartozhattak. Kivétel nélkül egy teljes panelméretet betöltenek, térbeliségüket tekintve vagy beépülnek a ház tömegébe vagy a tömegből kilógó konzolok. A mellvéd kialakítástól függően egy vagy három oldalról határolja a teret, zárt felület, esetleg díszített vagy áttetszö, átlátszó ( $F 1$, F2). A panelház homlokzatán az erkélyek, teraszok elhelyezése, a szigorú panelstruktúrától eltérő formálása és a betontól eltérő anyaghasználata a tervezői eszköztár egyik legfontosabb eleme volt. A lakás használata és energetikája szempontjából is lényeges, de a földszinten lévő átmeneti tér belső és külső határán, már az építés korában is problémásnak bizonyult, tervezetten vagy spontán módon, de megjelentek a bejutást gátló rácsok $(F 3, F 4)$, a belátást akadályozó árnyékolók. Az 1980-as évek végén - új lakhatási minőség érdekében - néhány panelházban a földszinti lakások elé betonfallal körbezárt magánkert épült.

KAPU (G1-G4. ÁBRA)

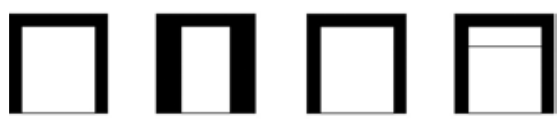

Panelházaknál a kapu nem a lakosok számára készült bejárat, hanem az épület gépészeti vagy egyéb kiszolgáló (hulladéktároló, egyéb tároló) helyiségeket vagy garázsokat feltáró nyílás, a funkció által meghatározott tömegtermék. Nagyobb mé- 
retü, pl. a szeméttároló konténer mozgatására alkalmas ajtó (G1) vagy az 1960-as, 1970-es évek autóira méretezett készárnyú, a betonfalba egyszerüen behelyezett fém- vagy fakapu. A garázskapuk általában panel szélesek (G2, G3), vagy más funkció esetén, kisebb nyílásként beépített, az épület földszintjén visszatérő elemek. Elöfordul, hogy a gyalogos mellékbejárat többfunkciós, így egyben a költözéseknél bútormozgatásra vagy hulladéktárolók kihordására is alkalmas kapu. Ilyenkor a kapu része egy átlátszó vagy áttetsző felület, mely biztonságosabbá teszi a terület használatát.
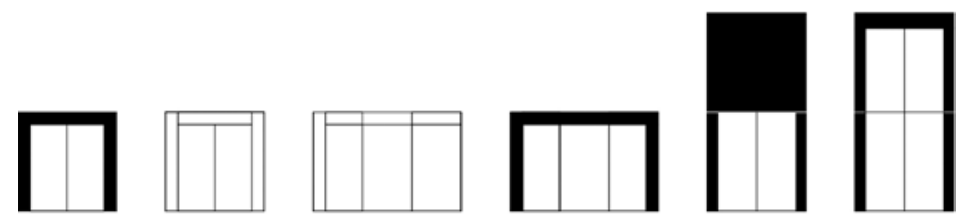

A házgyári épület típustervek nem tartalmaztak kereskedelmi, szolgáltató, vendéglátó helyiségeket a földszinten. Néhány épület esetén, melyek forgalmas úttal párhuzamosan, a lakótelepen belül központi helyen vannak, már építésük korában megjelentek a földszinten állami szolgáltató irodák. A rendszerváltást követő privatizáció és az életmódváltás az 1990-es évek elején hirtelen a földszintek belakását eredményezte: kisboltok és különböző magánszolgáltatók települtek be minden lehetséges helyre. Kirakat épült utólag a lábakon álló ház üvegpaneljének vagy funkcióvesztett volt kapuinak helyére vagy azok egy részére. A hazai környezetben tervezetlenek, sokfélék, tükrözik a terület társadalmi státusát, a lakók igényeit, az életszínvonalat. Jelenlétük, minőségük vagy hiányuk (a lakótelepek szélére épült boltok, a vásárlási szokások megváltozása az 1990-es évek végére a panel földszintek magánvállalkozásainak többségét ellehetetlenítették) egyértelmüen tükrözi az épített környezet, a lakótelep és a panelház adta fizikai és tágan értelmezett társadalmi (gazdasági, intézményi, kulturális stb.) állapotát.

KÖZÖS TEREK ABLAKA (I1-I5. ÁBRA)

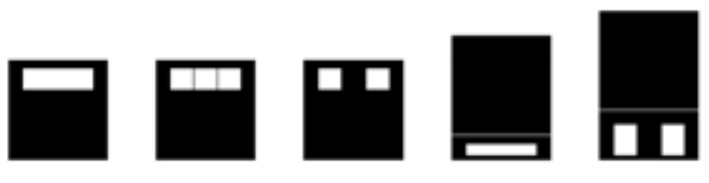


A földszinti homlokzaton lévő, minden alapsíkon álló, attól elemelt vagy lesülylyesztett, közösségi funkció megvilágítására szolgáló nyílás általánosan kisebb méretü, formai változatossága meglehetősen sokszínű, az épület egészétől független. Napjainkban biztonsági okokból általában berácsozott vagy nem is nyitható, hogy megakadályozzák a házba való bejutást. Méretük, formájuk - keskeny sávablakok vagy elszórt apró négyzetes nyílások - nem teszik lehetővé a huzamos tartózkodást, átalakítás nélkül a minőségi térhasználatot. Az eredeti elképzelés szerinti babakocsi-tároló vagy úgynevezett közös helyiség a földszinti funkció, a belső-külső kapcsolatteremtés lényegtelenségére utal.

\section{GÉPÉSZETI NYÍLÁS (J1-J9. ÁBRA)}

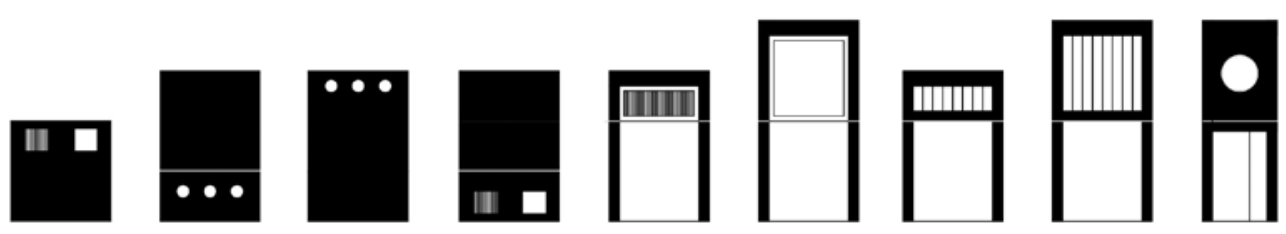

A paneles lakóházaknál gyakori, hogy a földszinti zóna az épületet ellátó gépészeti helyiségeké. A szellőzőnyílások megformálása egyedi stílusjegyeket is mutathat, például a falsíkban lévő vagy onnan kiugró kör $(J 2, J 9)$, négyszög keretek közé szerkesztett rácsok $(J 1, J 4)$, sorolt kicsi elemek $(J 2, J 3)$ vagy robosztus nagyok $(J 5, J 9)$ egyaránt ismertető jegyei egy-egy lakótelepnek, az építész tervező formáló szándékának lenyomatai.

\section{ÁTJÁRÓK}

A panel lakótelepeken, a sávházak részeként megjelentek átjárók is. Azzal a szándékkal készültek, hogy megtörjék az épület zárt fal jellegét és a használók számára rövidebb közlekedési útvonalat biztosítsanak, ne kelljen megkerülni a több száz méter hosszú házat vagy épületegyüttest. De a hely- és költséghatékony építés nem tett lehetővé a kortárs építészetben használt nagyméretü, a ház szerves részeként tervezett áttöréseket, helyette panelraszterben tartott, nyílás nélküli betonbütük közé feszített, akár tízszintes üres vagy funkció nélküli hidakkal tagolt rések vagy mindössze panelmagas földszinti ,aluljárók” teremtették meg az áthaladás lehetőségét. Az utolsó budapesti panel lakótelep, az 1980-as évek közepén posztmodern elvek alapján formált Káposztásmegyer átjárói már „nagyvonalúabbak”: íves záródású, két panel széles és másfél szint magas áttörések. 


\section{AZ ÉPÍTÉSZETI TÍPUSMEGOLDÁSOK HASZNÁLATI KÖVETKEZMÉNYEI}

Magyarországon a nagypaneles tömeges építés az 1960-as évek közepén kezdödött, Budapesten az első lakók 1967-ben költöztek be a kelenföldi lakótelep 10 szintes sávházaiba. A lakótelepek lehetséges és valós problémáira már építésük kezdetén és több nézőpontból is rávilágítottak szakemberek. Granasztói Pál „új lakótelepeink az urbanisztika mérlegén” alcímen az izolációról, a városiasság hiányáról, a monotóniáról és a fejlödésképtelenség veszélyéről ír (Granasztói 1968), a társadalmi problémákat - később a nemzetközi szakirodalom által is elismerten - két fiatal szociológus összegezte (Konrád \& Szelényi 1969). Közel fél évszázad távlatából pontosan értékelhetö, mennyire lényeglátó volt megközelítésük mind a fizikai, mind a társadalmi környezet vonatkozásában (Benkő 2016).

A földszinti zóna tipológiája nemcsak épület, hanem városrész, vagyis panel lakótelep léptékben is alkalmas a városiasság kérdéseinek elemzésére. A jelen írás a hazai panelföldszintek építészeti megoldásainak összefoglalását adja, rávilágít az ezekből adódó használati problémákra, felhívja a figyelmet a témakör kiemelt kezelésének fontosságára. Konkrét válaszok azonban kizárólag esettanulmányokra alapozva, a város, a lakótelep és maga az épület fizikai és társadalmi adottságaira reagálva jöhetnek létre, ezek ismertetése nem a kutatás tárgya (néhány példa a BME Urbanisztika Tanszék munkái között is található: http://www.urb.bme.hu/en/uhlab/prefabmh/). Az elméleti szinten általánosítható megállapítások közül a földszint és a szubjektív biztonságérzet összefüggéseinek bemutatása részletesebb, mivel a közbeszéd a lakótelepi környezethez ezt a problémát minden esetben társítja.

A paneles lakóépületek komplex felújításának szükségessége évtizedek óta ismert (Birghoffer 1994), a 2000-ben megindult állami panelprogram - mely eddig kb. a nagypaneles épületállomány negyedét érintette - azonban az energetikára épül, a külső felületek hőszigetelése, a nyílászárók cseréje általában a lakásokra korlátozódik és az épületfelújítás teljes mértékben figyelmen kívül hagyja a lépcsőházat és az életminőségben tényleges változások esélyét megteremtő földszinti zóna kezelését. Mozgatója pontosan ugyanaz a szemlélet, ami az építés idején is uralkodott: ipari háttérre támaszkodó tömegtermelés, tipizálás, gazdasági hatékonyság, látványos és gyors változás. 10 szintes panelház esetén a külső felület több mint $90 \%$-a új ruhát kap, a posztmodern színezés, melyben az épület egyre inkább csak építészeti tartalmaktól mentes festhető „,vászon”, a monotónia érzetét csökkenti, a telepet megjelöli. De a problémák többsége változatlan marad: a bejárati zóna, a lépcsőház, a földszinti helyiségek, a külső terek átalakulása nem része a programnak. Tényszerü és szomorú bizonyíték minderre, hogy Budapest mára már nem jogosan, de stigmatizált lakótelepe, a pestszentlőrinci Havanna lakásai, több évvel az európai és hazai pénzekből finanszírozott energetikai megújítás után is a legalacsonyabb eladási (lakás/ négyzetméter) áron értékesíthetők a panellakás ingatlanpiacon. Okai az izoláció, a városiasság hiánya, a viszonylagos fejlődésképtelenség (azonos házak és privatizált lakások), de elsősorban a társadalmi változások (Benkő 2015). (1-2. kép) 

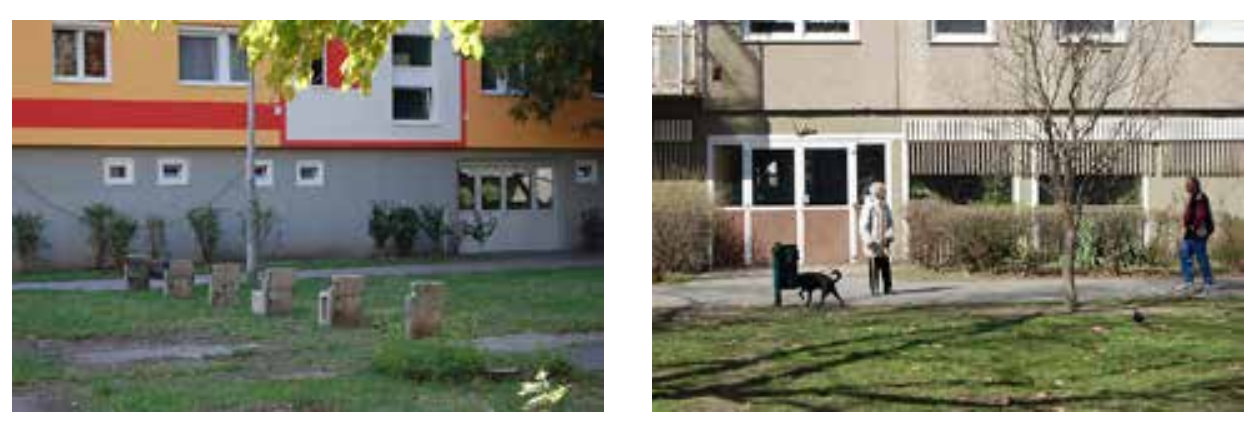

1-2. kép. Tízszintes felújított és felújítatlan panelház bejáratai a Havanna lakótelepen, Budapest (Fotó: Benkő Melinda, 2014)

A városiasság lényege nem kizárólag a sürüség (density), hanem az intenzitás (intensity). Ezt a lakótelepek és a kortárs lakóparkok világszerte egyértelmüvé teszik, hiszen sürün lakott városrészek, de a városiasság lényegét nem hordozzák, mivel gyenge az események, az emberek, a mozgások intenzitása. Alvó városok. Az intenzív várost a folyamatos változás is jellemzi, a generációk együtt élnek, müködik a társadalmi mobilitás. A közép- és kelet európai lakótelepekre azonban a rendszerváltozást követő privatizáció után beszorult egy generáció, a lakáspolitika és a támogatási rendszerek miatt pedig nincsenek új fiatal lakók, a népesség csökken és öregedik, az oktatási intézmények és a parkok kiürülnek. Már nemcsak alvó városok, mint fénykorukban, mikor a felnőtt aktív lakók napközben a város más részeit használták, de gyerekeik és szüleik megtöltötték élettel a telepet, hanem a napközbeni tétlenség helyszínei is.

A földszintek kialakítása, a tartószerkezeti és gépészeti kötöttségek ellenére tartalékot, térbeli felesleget mutat, befogadhatja a mai új lakhatási formák kiegészítő helyiségeit (pl. mosó- és szárítógépekkel felszerelt mosoda, közösségi étkezde), közösségi helyiségeket (pl. idősek napközi klubja, barkácsszoba, gyermekjátszó, sportszoba) vagy a külső terekkel összeköttetést adó funkciók tereit (pl. kerékpártároló, szerviz, kert-park ápoló, kisbolt stb.). A földszintek belakása a társadalmi fenntarthatóság megteremtésének hatékony eszköze, egymásra figyelö és segítő közösségek és egyének nyilvános tere, alapja a hétköznapi életminőség javulásának, és talán mozgatója hosszabb távú gazdasági, munkahelyteremtő helyi folyamatoknak.

A földszintek átalakítása, mivel a mindenki által szabadon használható közterületek magányos objektjei az úszótelkes panelházak, hozzájárul a lakótelepeket valós vagy elképzelt bünesetek alapján megbélyegző szubjektív biztonságérzet javításához. Napjainkban Magyarországon erre elsősorban az ipari háttérrel erősen támogatott, térfigyelö kamerák elhelyezése az általános megoldás, pedig ez a bünmegelőzés csak egyik lehetséges, az elidegenedést tovább erősítő eszköze a társadalmi (elsősorban nevelés és közösségi rendörség) és a környezeti mellett (Barabás et al. 2011).

A környezeti bünmegelőzés (CPTED - Crime Prevention through Environmental Design) elmélete és gyakorlata az 1960-as évekig nyúlik vissza. Egyik alapja Jane 
Jacobs, amerikai író urbanista Mire való a járda címủ írása (Jacobs 1961) és Oscar Newman, építész urbanista Védett terek címü könyve, ami 1972-ben jelent meg, ugyanabban az évben, mikor az általa térhasználat alapján elemzett St. Louis-i PruittIgoe lakótelep bontása lezajlott (Newman 1972). Azóta ez a lakótelep-robbantás a nyugati világ modern korszakának, a lakótelep-építésnek a jelképes vége (Jencks 1977), míg Közép- és Kelet-Európában az 1960-as években kezdődött nagypaneles tömeges lakótelep-építés mennyiségi csúcsa az 1980-as évek elején volt, és a „gyártás" egészen az 1990-es rendszerváltásig tartott. A világ sok részén, elsősorban Ázsiában pedig az ezredforduló még csak az urbanizáció hajnala, amit mai formában, sokszor nyugati szakemberek által tervezett költséghatékony és gyors lakótelep-, esetleg kerítéssel körbezárt lakóparképítés jellemez. Vagyis a lakótelep kérdéskör nem a múlté, problémáit és lehetőségeit globális léptékben örökítjük tovább a jövő generációnak.

A környezeti bünmegelőzés arra a kriminológiai felismerésre, az úgynevezett bünözés háromszög elméletre épít, hogy a támadó és az áldozat mellett a büntett harmadik eleme maga a helyszín. A helyszín milyensége, a térbeli és időbeli viszonyok mind befolyásolják a „szereplök”, vagyis a térhasználók viselkedését és biztonságérzetét. Vandalizmus, rongálás, tolvajlás, lopás, rablás, nemi erőszak stb. esetén a környezetalakítás általában szerepet játszik, de természetesen ez nem minden büncselekmény vagy deviáns viselkedéstípus esetében igaz (például a családon belüli erőszak, szervezett bünözés, gazdasági ügyek függetlenek a fizikai környezettől), illetve a terrorelhárítás vagy a közlekedésbiztonság is önálló szakterületként, más irányból közelít a kérdéshez. Az 1960-as évekbeli amerikai kezdetekhez képest Európában 1987-ben Barcelonában jött létre a települési önkormányzatok városbiztonsági kérdéseit koordináló szervezet, az European Forum for Urban Security (http://efus.eu/en/). Ezt követően felgyorsult a nemzetközi együttmüködés, az Európa Tanács 1989-ben konferenciát szervezett, a környezeti bünmegelőzés NagyBritannia, Hollandia, Dánia, Franciaország, Olaszország, Németország fontos multidiszciplináris kutatási és fejlesztési kérdésévé vált, illetve elveinek tudatos alkalmazása a városmegújításban segítette problémás lakókörnyezetek (pl. amszterdami, koppenhágai, manchesteri lakótelepek) biztonságának javítását. A sikerekre alapozva a 2004-es EU-bővítést követően több nemzetközi projekt indult, melyek eredményeként 2007-ben megjelent Safepolis kézikönyv (Safepolis 2007), a lakótelep-öszszehasonlításokat tartalmazó kutatás (Lukas 2007), és elkészült a CEN/TR 14383-2 számú EU-irányelv. Mindegyikben meghatározó szerepet kap a földszinti zóna kezelése, az átmeneti terek alakítása, a fizikai és társadalmi szempontok összehangolása. A környezeti bünmegelözés elveire alapozott építészeti beavatkozások helyszínei Nyugat-Európában leggyakrabban lakótelepek vagy új tömeges lakóterületek: Amsterdam Bijlmermeer, Barcelona Bellvitge (Benkő 2015), Lyon Confluence stb.

A téma multidiszciplináris jellege (kriminológia, szociológia, környezetpszichológia, építészet, tájépítészet) szakmaközi együttmüködést követel. Azonban a tudományos, a döntéshozói és a tervezési terület gyakran elbeszél egymás mellett, a hazai tudományos publikációk elsősorban kriminológiai megközelítésűek (Barabás 2008), 

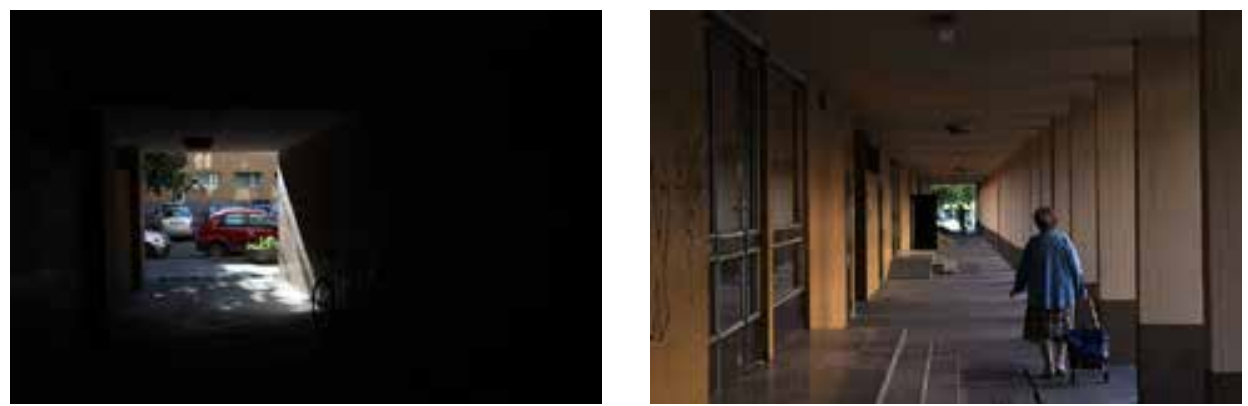

3-4. kép. Átjáró a sávház alatt és árkád mellette az Óbudai lakótelepen, Budapest

(Fotó: Tóth Fábián, 2015)

a politika számára nem igazán létezik ez az eszköz, ehelyett inkább a látványos és jól kommunikálható kamerarendszer telepítését preferálja, a tervezők pedig komoly elméleti ismeretek nélkül, elsősorban a nemzetközi köztér-rehabilitációk, épületátalakítások mintáit követve, esetleg ösztönösen alkalmazzák terveikben a környezeti bünmegelözés elemeit (3-4. kép).

A paneles lakótelepi környezet biztonságérzet szempontjából legproblémásabb helyei az árkádok, a deckek és az átjárók. Hazai lakótelepeken nem valósultak meg deckek, de a nemzetközileg elismert, építésük korában díjazott deckes mintalakótelepek mai megújításának első lépése ezek megszüntetése (pl. Toulouse Le-Mirail, Grenoble La Villeneuve, Amsterdam Bijlmermeer). Az árkádok a történeti városközpontok lényegi részei, esőtől védett kapcsolatteremtő terek az épület földszinti helyiségei (éttermek, boltok) és a külső városi tér között. A középmagas panelházak árkádjai alatt általában semmi nincs, sötét és gondozatlan, hatalmas vasbeton pillérek és zárt fal által közrezárt, a külsővel intenzíven kommunikáló földszinti funkciók és kiülők nélküli terek. Az épületen keresztül vezető átjárók - amelyek feladata a lakótelepen belüli közlekedési utak lerövidítése - pedig már a hazai lakótelepek többségében is ráccsal elzárt terek. Eredeti funkciója fontos, de mivel nem kíséri városias, a mozgásokat természetesen figyelő, akár 24 órás emberi jelenlét, veszélyes térrész. Pedig a paneles épületegyüttesek formai monotóniájának megtörésére ezek az eszközök álltak rendelkezésre: a tömeg felszakítása vertikálisan (átjárok, bejáratok, lépcsőházak) és horizontálisan (árkádok, erkélyek). Az építészeti díszítő próbálkozások (pl. paksi tulipánok, pécsi tv házak, káposztásmegyeri boltívek stb.) önmagukban, a földszinti zóna használati gazdagítása nélkül nem hoztak és hozhatnak ma sem eredményt. A müszaki megoldások, a fizikai környezet alakítása csak egy eleme a lakókörnyezet minőségjavításának, valójában a városon és az épületen belüli elzárkózás ellen kellene küzdeni. A földszintek - a szerkezeti lehetőségek szerint - kiszabadulva, új, elsősorban a lakókat szolgáló funkciókkal kapcsolatot teremthetnek nemcsak a külvilággal, hanem segíthetik az emberek egymásra találását, a kommunikációt, az odafigyelést, és ösztönözhetnek a közös és szabad terek használatára, sétára, mozgásra (Meggyesi 2013). A modernista lakótelep idea Közép- és Kelet-Európában ma 


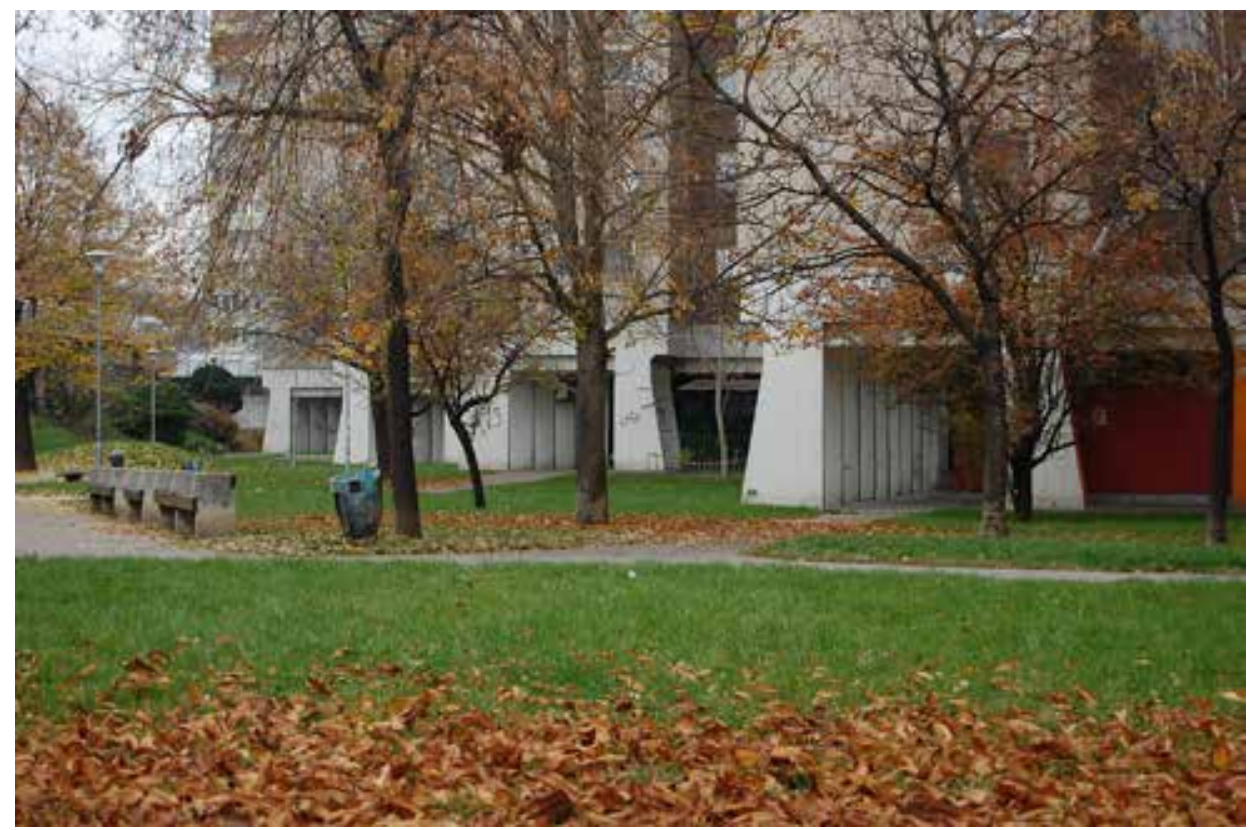

5. kép. Biztos lábakon (?) az Óbudai lakótelepen, Budapest (Fotó: Benkő Melinda, 2015)

még nem müködésképtelen, elfogadottsága megfelelő, imázsa javítható. A védett és elzárt terekkel, lakóparkokkal szemben befogadó, társadalmilag is fenntartható városrészekké lehet fejleszteni a lakótelepeket, 150 millió ember otthonát (Minton 2009).

\section{KONKLÚZIÓ}

A lakótelepek tényleges megújulása, a valós társadalmi változásokat is indukáló építészeti lehetőségek terepe a földszinti zóna. A napjainkra 30-50 éves hazai paneles lakótelepek természeti környezeti adottságai, az eredeti minőségi környezetalakításnak és az időnek köszönhetően, nagyon jónak értékelhetőek. Csend, jó levegö, benapozottság, beállt növényzet, közeli és esetleg távoli (panoráma) látvány, a modernista és a kortárs elveknek is megfelelő élettérre utal. Az eredeti beépítési koncepciók a fenntartható közlekedés alapelveit könnyen érvényesíthetővé teszik, a szabad terek többsége autómentes, a települési infrastruktúra a lakósűrüség révén hatékonyan müködtethető. A panelházak jelentős része már müszakilag megújított (fütéskorszerüsítés, hőszigetelés, ablakcsere), újabb évtizedekre biztosítja a normális lakhatási körülményeket, a lakásméretek a kortárs igényeknek, életmódnak egyre inkább megfelelnek. A földszinti zóna azonban felújítatlan és kihasználatlan, általában 
igénytelenséget, elhanyagoltságot tükröz, pedig számos egyéni és közösségi kezdeményezésnek teret adhat. A terület általában közös társasházi vagy önkormányzati tulajdon, ezáltal átalakítása közösségi döntést igényel. Kiváló terepe a kortárs moderátor építész szerepkör gyakorlásának, az építészeti megoldásokat előkészítő részvételi tervezésnek. A szakma kihívása a lakótelep városépítészeti újraértelmezése, a beépítés értékeinek feltárása, a területen belüli pozíciójától, méretétől függően az egyes panelházak elhanyagolt földszinti zónájának használati, térbeli és formai megújítása, a külső és belső kapcsolatok gazdagítása. A fundamentum megerősítése nélkül kérdéses a jövő.

\section{KÖSZÖNET}

A cikk az Magyar Tudományos Akadémia Bolyai János Kutatási Ösztöndíj támogatásával készült (BO/00162/13/6).

\section{IRODALOMJEGYZÉK}

Barabás Tünde - Dallos Endre - Kelenné Török Lívia - Nagy András - Ongjerth Richárd - Péti Márton - Sütő Attila - Tomay Kyra - Windt Szandra: Biztonságos város: Kézikönyv a városi bünmegelözés lehetőségeiröl. Belügyminisztérium \& VÁTI, Budapest 2011.

Barabás Tünde (szerk.): Épitett környezet - bünözés - szituációs bünmegelözés. Országos Kriminológiai Intézet, Budapest 2008.

Balla Regina: Horizontális hézag - a paneles lakóházak földszintje. TDK dolgozat. BME, Budapest 2014. http://tdk.bme.hu/EPK/DownloadPaper/Horizontalis-hezag-a-paneles-lakohazak (Utolsó megtekintés: 2015. 03. 21.)

Bélaval, Philippe (Ed.): Les grands ensembles - une architecture du XXe siecle. Carré, Paris 2011.

Benkő Melinda: „Külső és belső tér közti átmenetek - kontrasztok és áttűnések” című PhD-értekezésének vitája Schneller István és Vámossy Ferenc opponensi véleményével. Épités - Épitészettudomány 34 (2006) 1-2. 193-220.

Benkő Melinda: Lakótelepsors 4: Bellvitge, L’Hospitalet de Llobregat, Barcelona agglomeráció. Utóirat: A Régi-Új Magyar Épitömüvészet melléklete 15 (2015) 81. 45-46.

Benkö Melinda: The Lifespan of Large Prefabricated Housing Estates in Post-Communist Cities: An International Comparison. Architektúra \& Urbanizmus 49 (2015) 3-4. 180-197.

Benkő Melinda: Budapest's Large Prefab Housing Estates: Urban Values of Yesterday, Today and Tomorrow. Journal of Hungarian Studies 29 (2016) 1-2. 21-36.

Birghoffer Péter - Hikisch Lóránt (szerk.): A paneles lakóépületek felújitása. Müszaki Könyvkiadó, Budapest 1994.

Csízy László: A mikrostruktúra lehetőségei: Újpalotai közösségfejlesztés. In: Cságoly Ferenc (szerk.): Közösség és épitészet. BME Építőművészeti Iskola, Budapest 2012. 75-81.

Granasztói Pál: A hazai urbanisztika problémáiról. Társadalmi Szemle 23 (1968) 3. 30-39.

Építésügyi és Városfejlesztési Minisztérium Müszaki Tervezési Főosztály: Panelos lakóépületek típusterv katalógusa. Budapest 1976.

Hajnóczi J. Gyula: Vallum és intervallum - az épitészeti tér analitikus elmélete. Akadémiai Kiadó, Budapest 1992. 
Jacobs, Jane: "The Uses of Sidewalks: Safety". In: Jacobs, J.: The Death and Life of Great American Cities. Random House, New York 1961. (Magyarul: Kommentár 2008/2.)

Jencks, Charles: The Language of Post-Modern Architecture. Rizzoli, New York 1977.

Karlóczainé Bakay Eszter: Lakótelepek szabadtérépitészete 1945-1990 között Budapest példáján. Doktori értekezés, Budapesti Corvinus Egyetem, 2012. http://phd.lib.uni-corvinus.hu/605/3/ Bakay_Eszter.pdf (Utolsó megtekintés: 2015. 07. 21.)

Körner Zsuzsa - Nagy Márta: Az európai és a magyar telepszerü lakásépités története 1945-töl napjainkig. Terc, Budapest 2004.

Konrád György - Szelényi Iván: Az új lakótelepek szociológiai problémái. Akadémiai Kiadó, Budapest 1969.

KSH 2011. http://www.ksh.hu/docs/hun/xftp/idoszaki/nepsz2011/nepsz_orsz_2011.pdf (Utolsó megtekintés: 2014. 07. 11.)

Lukas, Tim (szerk.): Crime Prevention in High-Rise Housing. Lessons from the Crime Prevention Carousel. Kriminologische Forschungsberichte. Duncker \& Humblot, Berlin 2007.

Meggyesi Tamás: Promenadológia. Fejezetek a séta és a lineáris látványelemzés elméletéhez. Épités Épitészettudomány 41 (2013) 1-2. 145-189.

Minton, Ann: Ground Control: Fear and happiness in the twenty-first-century city. Penguin Books, London 2009.

Newman, Oscar: Defensible space - Crime prevention through urban design. Collier Books, New York 1972.

Safepolis: "Planning, urban design and management for crime prevention", Handbook, AGIS Action Safepolis, Politecnico di Milano, 2007. http://www.designforsecurity.org/uploads/files/A01_Handbook_English.pdf (Utolsó megtekintés: 2014. 07. 11.)

\section{FUNDAMENTUM - THE GROUND FLOOR AREA OF TOWER BLOCKS IN LARGE PREFAB HOUSING ESTATES}

\section{Summary}

The research hypothesis is that housing estate renewal demands a complex approach on the urban scale, a design which focuses on the ground floor area and the relation between interior and exterior space. The study analyses the stock of Hungarian tower blocks to create a typology - first, in terms of space limits (closed, translucent, transparent); and second, in terms of openings at the ground-floor level (entrance, window, balcony, gate, display window, technical installation opening, passage). The ground floor is a fundamental space layer, important for inhabitants and visitors alike. Nevertheless, it was neglected both at the time of construction and during the contemporary reconstruction process. Most technical and aesthetic solutions do not affect the ground floor; thus, the typical problems (space usage, poor subjective sense of security, and avoidance of common spaces) still remain. The paper summarizes the inherited architecture at the ground floor level of tower blocks, describes usage problems, and draws attention to the importance of the ground-floor area in the renewal of large prefabricated housing estates.

Keywords: large prefab housing estate, tower block, ground floor area, typology of space limits and openings, environmental crime prevention 